\title{
Small Scale Dairy Production Helps in Reduction of Poverty: Anecdotal Evidence
}

\author{
P.D. Shivagangavva*, G.S. Mahadevaiah and G.M. Gaddi
}

Department of Agriculture Economics, GKVK, Bangalore, Karnataka, India

*Corresponding author

\begin{abstract}
A B S T R A C T
Poverty is not only lack of income it is also a social phenomenon in which a section of a society unable to access the basic necessaries of the life. Even with implementation of poverty alleviation programme by government of India, the level of poverty has not decreased up to the mark in India. Hence in order to reduce poverty and to achieve the overall sustainable development in dairy sector, we study the poverty reduction among dairy and non-dairy farmers for This we have collected data from 120 dairy sample respondent and 60 non-dairy sample respondents from urban, transition and rural at North and South transect. Analysis was done by using poverty indicators (expenditure and standard of living) compare results with poverty line recommended by experts based that we classified into Above poverty line (APL) and below poverty line (BPL) in both dairy and non-dairy respondents. Results of the analysis revealed that raising dairy animals brought vast improvements to their lives, high scores on most of the indicators suggest that dairy sample households have better conditions than those of non-dairy sample households. Majority of the sample respondent fall under the Rs.2000-4000 expenditure category as they were small and marginal farmers so their spending was less in both dairy and non-dairy sample respondents but income was more in dairy sample respondents this shows income earned from dairy activity was more than non-dairy activity. Hence in dairy, farmers were able to get out of poverty and got improved their livelihood through small-scale dairy farming.
\end{abstract}

\section{Keywords}

Poverty, Dairy and

Non-dairy,

Expenditure, APL, BPL and Transects

\section{Article Info}

Accepted:

07 July 2019

Available Online:

10 August 2019

\section{Introduction}

Most widely and understood the definition of poverty is if the earning is less the $\$ 1.9$ a day, in another side word bank goes beyond the money and defined the poverty is hunger, lack of shelter, being sick and not being able to see a doctor, not having access to school and not knowing how to read, not having a job, is fear for the future, living one day at a time, losing a child to illness brought about by unclean water, it is powerlessness, lack of representation and freedom. Poverty line is the level of income to meet the minimum living conditions. Poverty line is the amount of money needed for a person to meet his basic needs.

According to the expert panel headed by former RBI governor C Rangarajan, those spending over Rs. 32 a day in rural areas and Rs. 47 in towns and cities should not be considered poor. Currently $21.9 \%$ population of India is under BPL. 
Poverty is mostly confined to those who are at the lowest ranks of the society. It is this section of the society that has benefited the most from the dairy cooperatives. Dairy sector plays an important role in providing health benefits, in supplementing family incomes, generating employment opportunity in rural as well as transition areas of small and marginal farmers and women. The regular income earned from the sale of milk has enlarged their perception on savings and investment and also enhanced their levels of aspiration. Hence, from the equity and livelihood perspectives it is considered as an important component in poverty alleviation programme. The pertinent research questions are whether dairy sector is changing the economic status of the dairy farmers in rural urban interface of Bengaluru. In which area dairy framers are benefiting more from the urbanization effect. What is status of changes in the livelihood security and economic status of dairy farmers and nondairy farmers. Keeping these issues under consideration, the present study was taken up in the two transects of Bengaluru i.e, South and North, which are having more impact of urbanization in the state the present study was undertaken with the following specific objectives

The main objectives of this study Impact of dairy enterprise in reducing the incidence of poverty among farmers.

\section{Materials and Methods}

The present study was conducted in the North and South transect of Bengaluru, Karnataka state. This study aimed at drawing a representative sample of villages across the rural-urban interface of Bengaluru, In the context of a larger study which investigates social-ecological transition processes in the rural-urban interface was conducted in the North and South transect of Bengaluru. For this we considered the per cent of build-up area and distance from the city centre using GIS analysis of satellite images, and combining basic measures of building density and distance. The correlation of the two parameters and discontinuities in the frequency distribution of the combined index indicate highly dynamic stages of transformation, spatially clustered in the ruralurban interface (Ellen et al., 2017). Sampling frame consist of dairy farmers from the two transects, North and South Bengaluru representing three layers (rural, transition and urban). A sample size of 50 households of dairy farmers from transition and rural layer and 20 from urban was selected randomly from the two transects to constitute a total sample of 240 household. In addition, 20 nondairy farmers from each layers from the transect we select. Thus, the total sample size was 360 and sample farmers were interviewed personally using a structured pre-tested schedule

\section{Poverty estimation}

Poverty can be estimated based on income method and expenditure methods. In this study, expenditure method proposed by $\mathrm{C}$ Rangarajan committee was employed. According to that poverty line based on certain normative levels of adequate nourishment, clothing, house rent, conveyance and education, and a behaviourally determined level of other non-food expenses.

Family size is converted into family equivalent scale i.e.

$<14$ age -0.75

$14-60-1.00$

$>60-0.75$

According Rangarajan poverty line per day per capita was Rs.32 for rural, transition 39.5 and Rs. 47 for urban during 2014. 
Since data is not available for the transition, average value of urban and rural area is considered for the transition. These standards were calculated for the year 2018 by considering the whole sale price index in order to see the inflation then we arrived the values are Rs.47.41 for urban, Rs.39.89 for transition and Rs.32.28 for rural area were considered. The poverty line (APL) and (BPL) for the study was fixed by considering the standardised value per day per capita expenditure.

\section{Results and Discussion}

\section{Poverty estimation}

\section{Different category of expenditure for poverty estimation}

The information on monthly expenditure per rural household was collected and the monthly expenditure was categorised in to four groups. Further, households have been distributed across these four categories of expenditure and results are presented in table 1.

In case of dairy sample households, about 57 per cent of households come under the expenditure category of Rs.2000 to Rs.4000 per month and 25 per cent of households come under expenditure category of upto Rs.2000 per month. Similarly, in case of non-dairy sample households, about 65 per cent and 28 per cent of households come under the expenditure category of Rs.2000 to Rs.4000 per month and upto Rs.2000 category, respectively. Interestingly, meagre proportion of only (4\% and 1\%) of the households showed expenditure of Rs.6000 to Rs.8000 correspondingly in the case of dairy and nondairy sample households.

Among the three layers of dairy sample households, as high as 65 per cent and 70 per cent of households fall under Rs.2000-4000 category of expenditure correspondingly in urban and rural layer and 54 per cent of households fall under Rs.2000 category of expenditure in transition layer in north transect, while in south transect, the highest that is $(75, \% 54 \%$ and $54 \%)$ of households fall under Rs.2000-4000 category of expenditure correspondingly in the case of urban, transition and rural layer, respectively.

In non-dairy sample households, the highest proportion of households fall under the monthly expenditure category of Rs.20004000 in urban $(85 \%)$, transition $(80 \%)$ and rural $(70 \%)$ layer of north transect, while in south transect, 65 and 70 per cent of sample households fall under the Rs.2000-4000 expenditure category correspondingly in urban and transition layers and 80 per cent of sample respondent fall under the Rs.0-2000 expenditure category in rural layer.

Based on the above results, we can infer that majority of the sample respondent fall under the Rs.2000-4000 expenditure category as they were small and marginal farmers so their spending was less. These findings are in confirmatory with similar findings reported by Janjua (2011) in a cross-country analysis by using UN data source, where they have concluded that income growth plays a moderately positive role in alleviating poverty.

\section{Poverty reduction}

The results regarding poverty reduction due to practice of dairying among dairy and nondairy sample households is presented in (Fig. 1 and 2). In dairy sample households, the poverty reduction was observed across all the layers of both North and South transect except rural layers of South transect. Whereas in nondairy, farmers poverty existed among the farmers in all the three layers of urban (10\%), transition (12\%) and rural (4\%) in North transect, while in South transect there was no poverty except in rural (25\%) layer. 
Tables.1 Classification of sample respondents based on monthly on expenditure in the study area

\begin{tabular}{|c|c|c|c|c|c|c|c|c|c|c|c|c|c|c|c|}
\hline \multirow{3}{*}{$\begin{array}{l}\text { Sl. } \\
\text { No. }\end{array}$} & \multirow{3}{*}{$\begin{array}{c}\text { Particulars } \\
\text { (Rs. /Months) }\end{array}$} & \multicolumn{6}{|c|}{ Dairy sample respondents } & \multirow[t]{3}{*}{ Pooled } & \multicolumn{6}{|c|}{ Non- Dairy sample respondents } & \multirow[t]{3}{*}{ Pooled } \\
\hline & & \multicolumn{3}{|c|}{ North transect $(n=120)$} & \multicolumn{3}{|c|}{ South transect $(n=120)$} & & \multicolumn{3}{|c|}{ North transect $(n=60)$} & \multicolumn{3}{|c|}{ South transect(n=60) } & \\
\hline & & Urban & Transition & Rural & Urban & Transition & Rural & & Urban & Transition & Rural & Urban & Transition & Rural & \\
\hline \multirow[t]{2}{*}{1} & \multirow[t]{2}{*}{$0-2000$} & 5 & 27 & 13 & 2 & 9 & 5 & 61 & 1 & 3 & 2 & 6 & 5 & 16 & 33 \\
\hline & & $(25)$ & (54) & (26) & $(10)$ & $(18)$ & $(10)$ & $(25.42)$ & $(5)$ & $(15)$ & $(10)$ & $(30)$ & $(25)$ & $(80)$ & $(27.50)$ \\
\hline \multirow[t]{2}{*}{2} & \multirow[t]{2}{*}{$2000-4000$} & 13 & 21 & 35 & 15 & 27 & 27 & 138 & 17 & 16 & 14 & 13 & 14 & 4 & 78 \\
\hline & & (65) & (42) & (70) & (75) & (54) & (54) & $(57.50)$ & (85) & (80) & (70) & (65) & (70) & (20) & $(65.00)$ \\
\hline \multirow[t]{2}{*}{3} & \multirow[t]{2}{*}{$4000-6000$} & 2 & - & 2 & 2 & 13 & 13 & 32 & 2 & 1 & 3 & 1 & 1 & - & 8 \\
\hline & & (10) & & (4) & (10) & (26) & (26) & (13.33) & (10) & (5) & (15) & (5) & (5) & & (6.67) \\
\hline \multirow[t]{4}{*}{4} & \multirow[t]{2}{*}{$6000-8000$} & \multirow[t]{2}{*}{-} & 2 & \multirow[t]{2}{*}{ - } & 1 & 1 & 5 & 9 & \multirow[t]{2}{*}{ - } & \multirow[t]{2}{*}{-} & 1 & \multirow[t]{2}{*}{-} & \multirow[t]{2}{*}{-} & \multirow[t]{2}{*}{-} & 1 \\
\hline & & & (4) & & (5) & (2) & (10) & $(3.75)$ & & & (5) & & & & $(0.83)$ \\
\hline & \multirow[t]{2}{*}{ Total } & 20 & 50 & 50 & 20 & 50 & 50 & 240 & 20 & 20 & 20 & 20 & 20 & 20 & 120 \\
\hline & & (100) & (100) & (100) & (100) & (100) & (100) & (100) & (100) & (100) & (100) & (100) & (100) & (100) & (100) \\
\hline
\end{tabular}

Note: Figures in parenthesis is the percentage to the column total

Fig.1 Poverty reduction among sample respondents in north transect
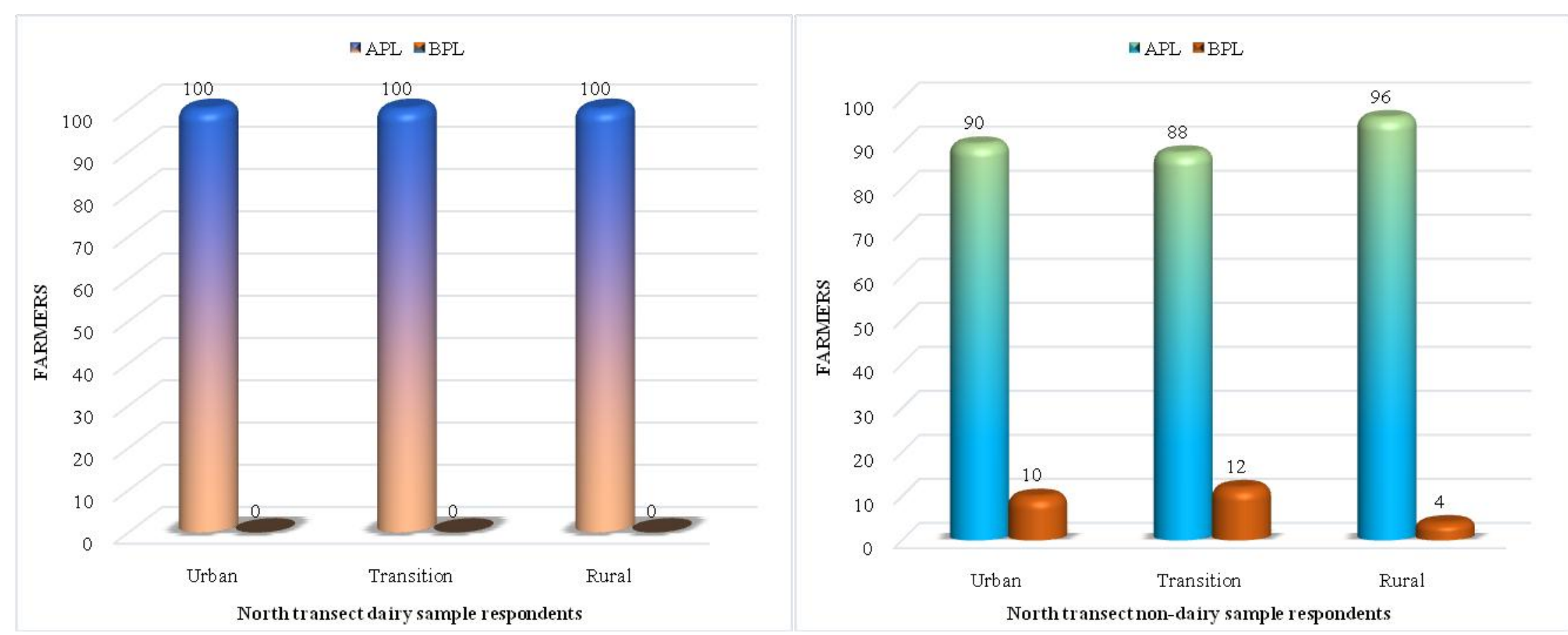


\section{Int.J.Curr.Microbiol.App.Sci (2019) 8(8): 707-712}

Fig.2 Poverty reduction among sample respondents in south transect
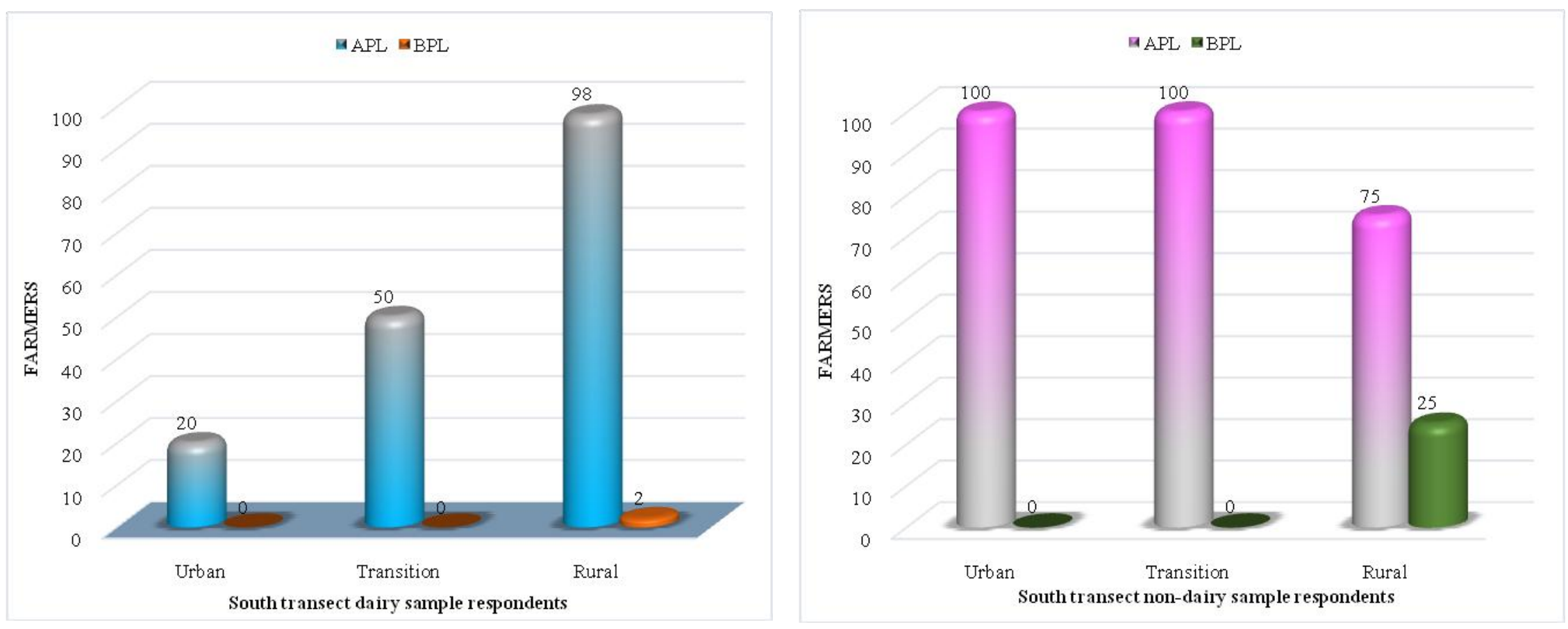
These Figures 1 and 2 clearly indicated that, the dairy is the one of those activities which helps to up lift the farmers from the poverty. Hence, small-scale dairy farming is considered as a strong instrument in the improvement of the farmers' economy in Bengaluru district. Poverty reduction indicators have been used to assess the level of poverty situation in both dairy and nondairy respondents. Raising dairy animals brought vast improvements to their lives. High scores on most of the indicators suggest that dairy sample households have better conditions than those of non-dairy sample households. In dairy, farmers were able to get out of poverty and got improved their livelihood through small-scale dairy farming.

The study revealed that the proportional expenses on dairying was less compare to non-dairy expenditure at the household level is inversely related to income. Therefore, dairying has the capacity to reduce poverty at the household level and it should be an integral part of poverty alleviation programmes. The income from dairy farming reduces the income inequality. It also confirms that growth dairying sector does not worsen income distribution, but helps in reducing absolute poverty and inequality. Promotion of standard of living and reduction of poverty will depend on the capacity of dairy farming to contribution for smallholder income and employment.

\section{References}

Awojobi, and Nathaniel O. 2014. Microfinance as a strategy for poverty Reduction in Nigeria: Empirical investigation. International Journal of Current Research., 6 (9):8944-8951.

Ellen, M. H., Monish, J., Nils, N. and Thomas, M. 2017. Construction and use of a simple index of urbanization in the rural-urban interface of Bangalore, India. Sustainability, 1-21.

Rangarajan, 2014. Report on poverty estimation, Government of India Planning Commission: 1-92

Tanwar, P. S. 2015. Impact of dairy cooperatives on milk production, income and employment generation in semi-arid Rajasthan. International Journal in Management and Social Science, 3(3): 477-487.

Yasmen, S. and Ikemoto, Y., 2015, Women's Participation in Small-Scale Dairy Farming for Poverty Reduction in Bangladesh. American International Journal of Social Science, 4(5): 1-13.

\section{How to cite this article:}

Shivagangavva, P.D., G.S. Mahadevaiah and Gaddi, G.M. 2019. Small Scale Dairy Production Helps in Reduction of Poverty: Anecdotal Evidence. Int.J.Curr.Microbiol.App.Sci. 8(08): 707712. doi: https://doi.org/10.20546/ijcmas.2019.808.080 